\title{
Analysis of Genetic Variation in the Natural Populations of Clarias batrachus from India Using Microsatellite Markers
}

\author{
Nimmy Jousy ${ }^{1}$, Shrinivas Jahageerdar ${ }^{1 *}$, J. Krishna Prasad ${ }^{2}$ and P. Gireesh Babu ${ }^{1}$ \\ ${ }^{1}$ Division of Fish Genetics and Biotechnology, ICAR-Central Institute of Fisheries Education, \\ Mumbai- 400061, Maharashtra, India \\ ${ }^{2}$ CTO, Kakinada Research Centre of ICAR-Central Institute of Fisheries Education, \\ Kakinada- 533 001, Andhra Pradesh, India \\ *Corresponding author
}

\section{A B S T R A C T}

\section{Keywords}

C. batrachus, Genetic variation, Magur,

Microsatellite.

Article Info

Accepted:

17 July 2017

Available Online:

10 September 2017
The present study was aimed to analyze the genetic variation $C$. batrachus (Magur) from three natural population viz., Andhra Pradesh, Assam and West Bengal states of India using the microsatellite markers. Four microsatellites showed high polymorphism with allele numbers ranging from 4 to 9 . Observed heterozygosity at each locus was more than 0.50 and the polymorphic information content (PIC) for the four loci ranged from 0.62 to 0.82 , indicating that these loci can be used discriminate Magur populations of India. $F_{\text {ST }}$ values ranged from 0.072 to 0.098 and it appears that there was little genetic differentiation between the Magur populations.

\section{Introduction}

Clarias batrachus, is an air breathing catfish and popularly known as Magur in India. The genus Clarias is present in both the Asian and African continents (Teugels, 1996). C. batrachus is widely distributed apart from India, in Bangladesh, Indonesia, Malaysia, Myanmar, Pakistan, Philippines, Singapore, Sri Lanka and Thailand (Khan et al., 2000). The fish normally inhabits swamps, marshy and derelict water bodies though it is also found in open water systems (CAFF, 2006). There is a great demand for Magur in the Indian domestic market and is mainly met through river based capture fisheries.
Its abundance has been greatly reduced by overexploitation and by serious destruction and fragmentation of most aquatic ecosystems, particularly from injudicious application of insecticides in the paddy fields, the most common place for spawning (Nasren et al., 2009). The species has already been categorized as vulnerable based on the IUCN Red List categories of 1994 in India (Dahanukar et al., 2004; Garag et al., 2010). Therefore there is a need for conservation of the species. For conservation of species or population it is essential to study the genetic variation both between and within them. 
Despite the demand, catfish aquaculture is still in the primary phase, and mainly depends on the seed collected from wild which puts the pressure on natural stock. Hence the efficient management of the available natural stock is very crucial for the existence of the species and its various populations. For the development of management strategies to conserve biodiversity, information on population structure is important (Turan et al., 2005). Genetic diversity helps in adaptation and survival of the species and is considered as an important factor for the conservation and management of populations (Andayani et al., 2001).

The advancements in molecular marker and statistical tools had revolutionized the analytical power needed for the exploration of genetic diversity (Tamanna et al., 2012). Garg et al., (2010) and Danish et al., (2012) have studied $C$. batrachus populations in India using RAPD markers, however there are no reports to the best of our knowledge on the study of genetic variation between Magur populations from different states of India using microsatellite markers.

Microsatellite DNA markers detect codominant polymorphism at simple sequence repeats and generate large number of detectable alleles (Tautz, 1989) and can be used to analyze the genetic structure and genetic diversity among the natural population. They have a number of advantages in aquaculture and fisheries research over other molecular markers (O'Reilly and Wright, 1995). Microsatellite markers have been isolated from several Clarias species including $C$. batrachus (Galbusera et al., 1996; Na-Nakorn et al., 1999; Volckaert et al., 1999; Yue et al., 2003; Senanan et al., 2004, Mohindra et al., 2012a, b; Srivastava et al., 2016). These markers have been found to be highly polymorphic and are better suited for population studies.
The objective of this study was to analyze the genetic variation in three natural populations of $C$. batrachus from India using the microsatellite markers.

\section{Materials and Methods}

\section{Sample collection}

For the present study, Magur fishes were collected with the help of local fishermen from their natural habitat from Andhra Pradesh, Assam and West Bengal states of India during 2012-13 to initiate a selective breeding program (Fig. 1). The Andhra Pradesh population was collected from Lake Kolleru, a natural wetland ecosystem formed as a basin between the deltas of the peninsular rivers Godavari and Krishna.

Assam fishes were collected from paddy fields around Guwahati, while the West Bengal Fishes were collected from swamps around Kolkata. The total length of the collected fishes ranged from 9.0 to $25.0 \mathrm{~cm}$ and body weight from about 15 to $95 \mathrm{~g}$. The dorsal fin tissue measuring about $6-10 \mathrm{~mm}$ was incised with the help of a BP blade from fresh specimen and individually stored in 100 percent ethanol. The samples were then transported to the laboratory under refrigerated conditions and in laboratory were kept at $-20^{\circ} \mathrm{C}$ till further analysis.

\section{DNA extraction and microsatellite analysis}

Genomic DNA was extracted from 50-100 mg of preserved fin sample by phenolchloroform extraction method. Briefly, the tissue was lysed overnight at $55^{\circ} \mathrm{C}$ (in a water-bath) in $0.6 \mathrm{ml}$ of lysis buffer (TEN buffer, $\mathrm{pH} 8.0$, and $1 \% \mathrm{SDS}$ ) and $6 \mu \mathrm{l}$ of Proteinase K $(20 \mathrm{mg} / \mathrm{ml})$. The reaction mixture was extracted with Phenol: Chloroform: Isoamyl alcohol (25:24:1), precipitated with alcohol, and then dissolved 
in 1X TE buffer (pH 8.0) (Sambrook et al., 2001).

In the present study four microsatellite loci namely CbSpn-1115, CbSpn-1191, CbSpn0449 (Mohindra et al., 2012b) and Cba-19 (Yue et al., 2003) were employed for the genetic diversity analysis of $C$. batrachus populations. PCR was performed in $25 \mu 1$ reaction volume comprising $1 \mathrm{x}$ PCR buffer, 3 $\mathrm{mM} \quad \mathrm{MgCl} 2, \quad 0.2 \mathrm{mM}$ each dNTP 10 picomoles of each primer and 1 unit of Taq DNA polymerase (Thermo Scientific, USA). The annealing temperature was optimized as 49, 55, 50 and $62.5^{\circ} \mathrm{C}$ for CbSpn-1115, CbSpn-1191, CbSpn-0449 and Cba-19, respectively by gradient PCR. The PCR conditions included an initial denaturation 5 min at $94^{\circ} \mathrm{C}$ followed by 30 cycles of $1 \mathrm{~min}$ at $94^{\circ} \mathrm{C}, 1 \mathrm{~min}$ at optimal annealing temperature and $1 \mathrm{~min}$ at $72^{\circ} \mathrm{C}$, with final extension of 7 $\min$ at $72^{\circ} \mathrm{C}$. Amplification products were resolved on $10 \%$ and $8 \%$ non-denaturing polyacrylamide gel, and visualized by ethidium bromide staining. Generuler 100bp DNA ladder (Thermo Scientific, USA) was run along with the amplified samples to determine the allele size using Image $\mathbf{J}$ software.

\section{Data analysis}

Allele frequencies, number of alleles per locus, expected and observed heterozygosity, allelic diversity, genotype frequencies and Chi-square test to determine the deviation from Hardy -Weinberg equilibrium for each locus were calculated using PROC ALLELE procedure in SAS software (Saxton, 2004). The presence or absence of linkage disequilibrium between the marker loci was also determined. Software GenAlex version 6.5 (Peakall and Smouse 2012) was used to analyze all other study parameters. The fractions of the total genetic variation distributed among populations were estimated using the $\mathrm{F}_{\mathrm{st}}$ statistic (Lynch and Crease, 1990).

\section{Results and Discussion}

The number of alleles observed and expected heterozygosity and polymorphic information content (PIC) of the four microsatellite loci used in the present study are summarized in table 1. All the four microsatellite loci were found to be highly polymorphic in the studied populations of $C$. batrachus. The highest number of alleles (9) was observed for the Cba-19 locus in Andhra Pradesh population (Table 1), while the maximum numbers of alleles at Cbspn-1191, Cbspn-1115, and Cbspn-0449 loci were 8, 6 and 4, respectively (Table 1). The average number of alleles (6.5) was the highest in Andhra population (Fig. 2). The effective number of alleles in different populations was $0.55,0.34$ and 0.79 for Andhra Pradesh, Assam and West Bengal, respectively (Fig. 2). Allelic pattern of all the four microsatellite loci in each population is shown in figure 2. Private alleles were found in all the loci except Cbspn-1191 (Table 2, Fig. 2). The frequency of private alleles, sizing $175 \mathrm{bp}$ and $209 \mathrm{bp}$, in Assam stock was relatively high when compared to other alleles of other loci.

The PIC value ranged from $0.62-0.82$ across the loci with highest at Cba-19 locus in Andhra Pradesh and West Bengal populations (Table 1). The observed heterozygosity $\left(\mathrm{H}_{\mathrm{o}}\right)$ or the allelic diversity was highest for the Cbspn-0449 locus which was higher than the $\mathrm{H}_{\mathrm{e}}$ in all the three populations. Cba-19 locus in all the three populations and Cbspn- 1191 in Andhra Pradesh population were found to be in Hardy-Weinberg equilibrium (HWE) (P>0.05) while the other two loci showed significant deviation from HWE.

The coefficient of genetic differentiation $\left(\mathrm{F}_{\mathrm{st}}\right)$ ranged from $0.042-0.15$ (Cbspn 1115 and 
Cbspn 0449, respectively; Table 3) with a mean of 0.087 . The pair-wise $F_{\text {st }}$ values ranged 0.02 to 0.09 , which signified low level of genetic differentiation in the studied populations of $C$. batrachus. The pair-wise genetic differentiation of Assam stock with the other two stocks was on a higher side than those with Andhra and West Bengal populations. AMOVA based on microsatellite data indicated $8 \%$ genetic differentiation among populations $(\mathrm{P}<0.05)$ (Table 4, Fig. 3)

Genetic characterization of the natural populations is essential to assess the gene flow, impact of mutation, migration, selection and genetic drift and further to draw the management practices. For this purpose, microsatellite markers have proven to be extremely important tools because of their high polymorphism, abundance and codominance (Liu and Cordes, 2004). In the present study the level of polymorphism and the heterozygosity values of four microsatellite markers were taken as measures of genetic diversity in three natural populations of $C$. batrachus in India. The allelic diversity and heterozygosity can measure the adaptive diversities of a population. Preliminary genetic variability studies using microsatellite markers have earlier been done for South East Asian populations of $C$. batrachus by Yue et al., (2003) Volckaert et al., (1998) and in India by Mohindra et al., (2012b).

Fig.1 Map showing three different sampling sites of C. batrachus natural populations

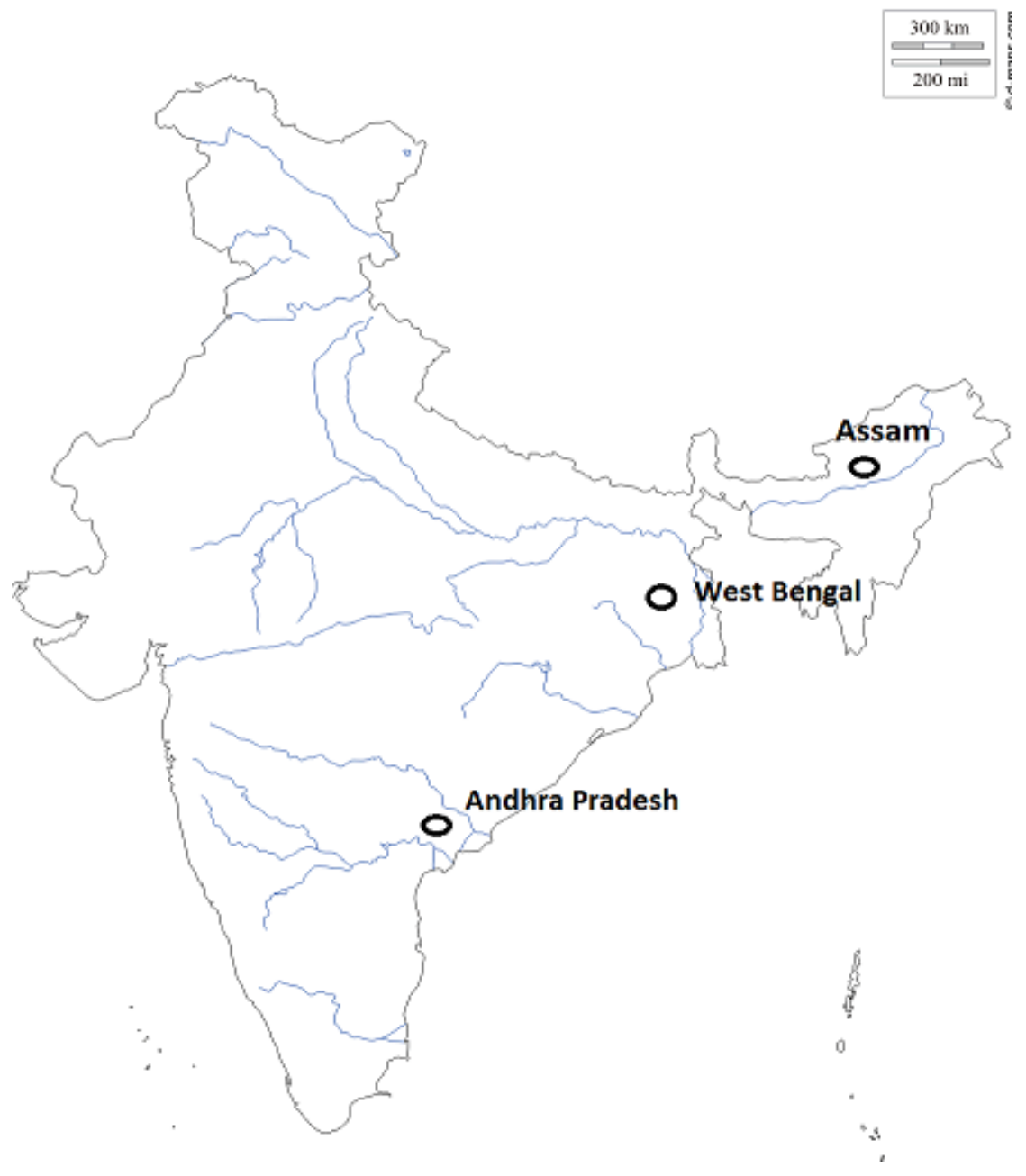


Fig.2 Allelic pattern across Magur population of Andhra Pradesh (AP), Assam (AS) and West Bengal (WB) populations

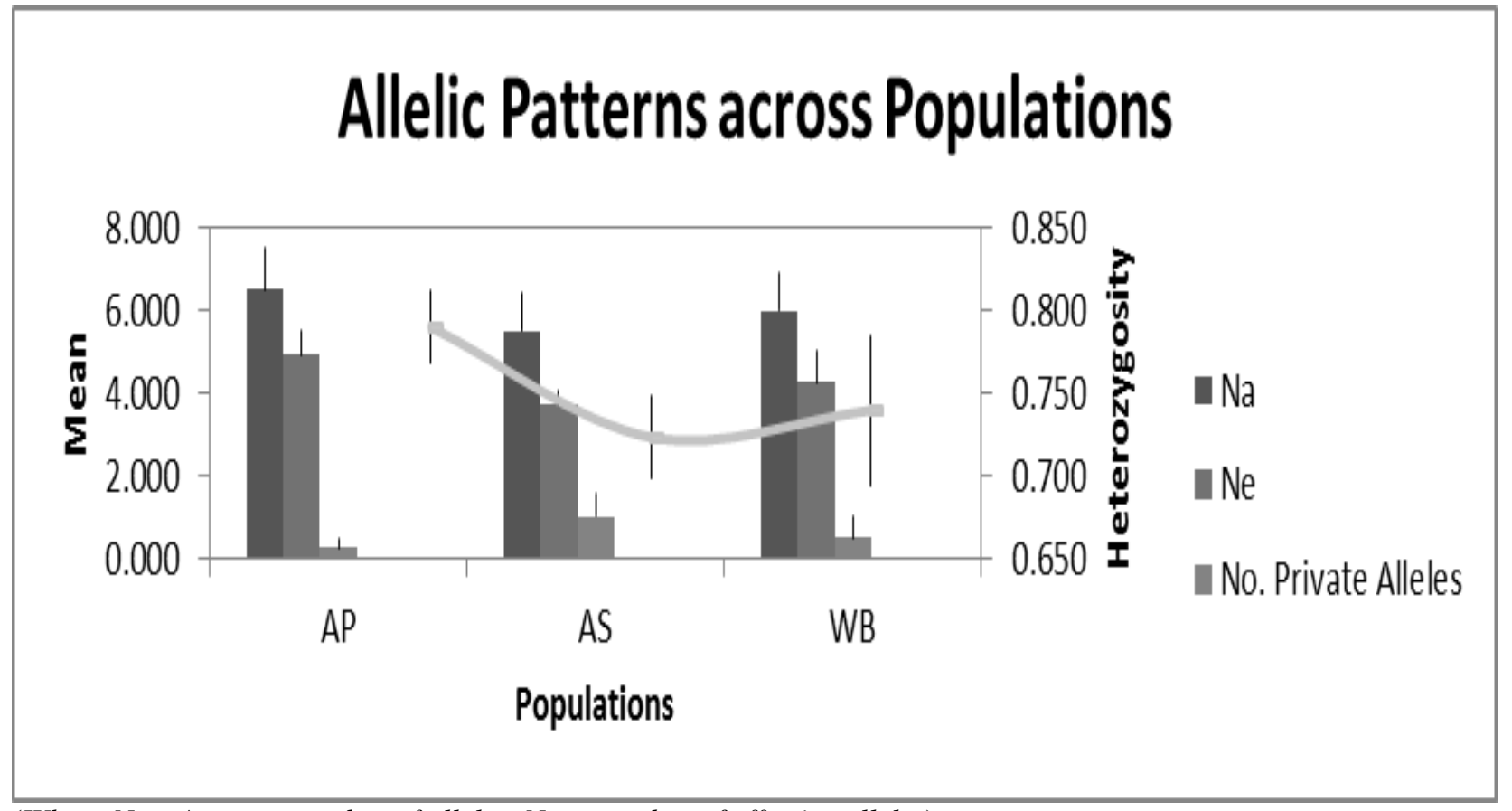

(Where $\mathrm{Na}=$ Average number of alleles, $\mathrm{Ne}=$ number of effective alleles)

Fig.3 Pie diagram showing the percentage of molecular variance among three populations of $C$. batrachus

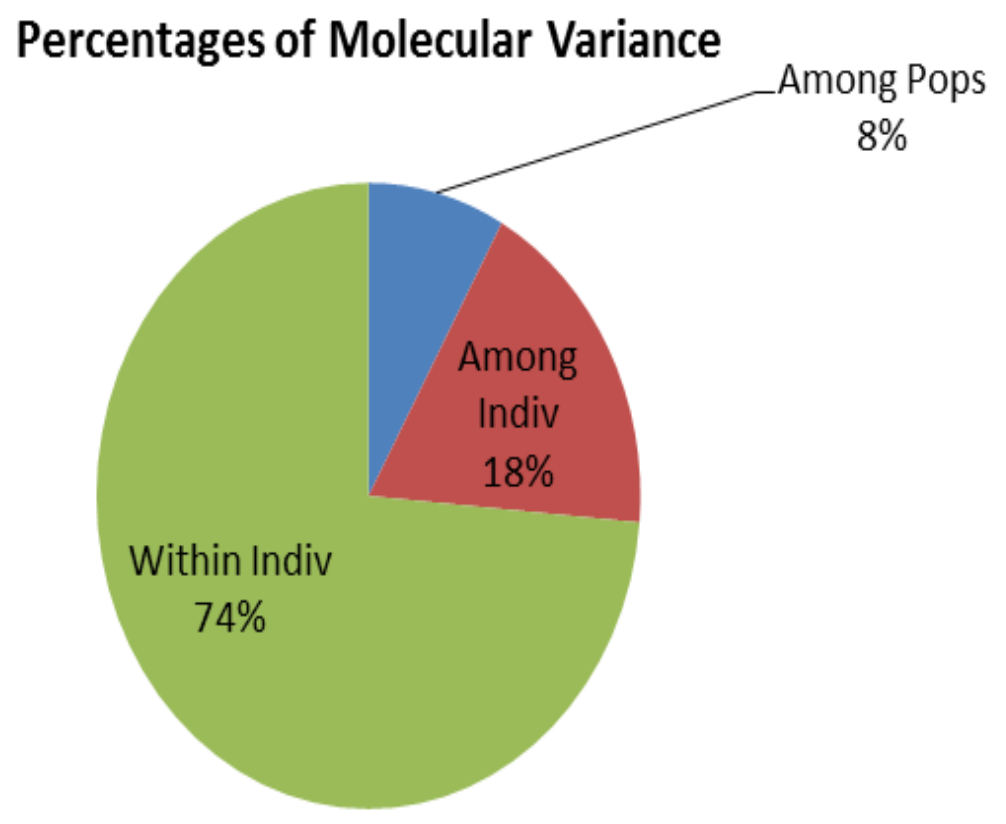


Table.1 Number of individuals, number of alleles (NA), Polymorphic information content (PIC), observed heterozygosity $\left(\mathrm{H}_{\mathrm{o}}\right)$, expected heterozygosity $\left(\mathrm{H}_{\mathrm{e}}\right)$ and Hardy Weinberg Expectation $(\mathrm{P}<0.05)$ of four microsatellite markers used in Andhra Pradesh (AP), Assam (AS) and West

Bengal (WB) natural populations of Magur

\begin{tabular}{|l|l|r|r|r|}
\hline Locus & & AP & AS & WB \\
\hline Cbspn-1191 & N & 17 & 11 & 12 \\
\hline & No. alleles & 7 & 8 & 7 \\
\hline & PIC & 0.78 & 0.79 & 0.76 \\
\hline & $\mathrm{H}_{\mathrm{o}}$ & 0.52 & 0.63 & 0.80 \\
\hline & $\mathrm{H}_{\mathrm{e}}$ & 0.81 & 0.82 & 0.79 \\
\hline & HWE & $* *$ & $*$ & $*$ \\
\hline Cbspn-1115 & $\mathrm{N}$ & 16 & 12 & 14 \\
\hline & No. alleles & 6 & 4 & 5 \\
\hline & PIC & 0.72 & 0.64 & 0.61 \\
\hline & $\mathrm{H}_{\mathrm{o}}$ & 0.82 & 0.50 & 0.50 \\
\hline & $\mathrm{H}_{\mathrm{e}}$ & 0.76 & 0.69 & 0.65 \\
\hline & $\mathrm{HWE}$ & $*$ & $*$ & $*$ \\
\hline & $\mathrm{N}$ & 16 & 13 & 14 \\
\hline & No. alleles & 9 & 6 & 8 \\
\hline & PIC & 0.82 & 0.72 & 0.82 \\
\hline & $\mathrm{H}_{\mathrm{o}}$ & 0.62 & 0.69 & 0.85 \\
\hline & $\mathrm{H}_{\mathrm{e}}-19$ & 0.84 & 0.75 & 0.83 \\
\hline & $\mathrm{HWE}$ & $* *$ & $* *$ & $* *$ \\
\hline & $\mathrm{N}$ & 17 & 12 & 13 \\
\hline & No. alleles & 4 & 4 & 4 \\
\hline Cbspn-0449 & PIC & 0.72 & 0.62 & 0.62 \\
\hline & $\mathrm{H}_{\mathrm{o}}$ & 1 & 1 & 1 \\
\hline & $\mathrm{H}_{\mathrm{e}}$ & 0.74 & 0.68 & 0.68 \\
\hline & HWE & $*$ & $*$ & $*$ \\
\hline
\end{tabular}

** No deviation from HWE, * significant deviation from $\mathrm{HWE}(\mathrm{P}<0.05)$

Table.2 Frequency of private alleles of four microsatellite markers found in Andhra Pradesh (AP), Assam (AS and West Bengal (WB) natural populations of Magur fish

\begin{tabular}{|l|l|l|l|}
\hline Pop & Locus & Allele size (base pair) & Freq \\
\hline AP & Cba-19 & 223 & 0.059 \\
\hline AS & Cbspn-1115 & 135 & 0.038 \\
\hline AS & Cbspn-1115 & 147 & 0.115 \\
\hline AS & Cbspn-0449 & 175 & 0.385 \\
\hline AS & Cbspn-0449 & 209 & 0.385 \\
\hline WB & Cbspn-1115 & 211 & 0.071 \\
\hline WB & Cbspn-1115 & 219 & 0.071 \\
\hline
\end{tabular}


Table.3 Analysis of genetic differentiation between pairs of Andhra Pradesh (AP), Assam (AS) and Wes Bengal (WB) population based on estimates of $F_{s t}$

\begin{tabular}{|l|l|r|}
\hline Population 1 & Population 2 & Pair-wise population $\mathbf{F}_{\text {st }}$ \\
\hline AP & AS & 0.072 \\
\hline AP & WB & 0.029 \\
\hline AS & WB & 0.098 \\
\hline
\end{tabular}

Table.4 Analysis of molecular variance (AMOVA) showing genetic differentiation

\begin{tabular}{|l|r|r|r|r|r|}
\hline \multicolumn{1}{|c|}{ Source } & \multicolumn{1}{c|}{ df } & \multicolumn{1}{c|}{ SS } & \multicolumn{1}{c|}{ MS } & Est. Var. & \multicolumn{1}{c|}{$\%$} \\
\hline Among Pops & 2 & 11.903 & $5.951^{*}$ & 0.140 & $8 \%$ \\
\hline Among Individual & 41 & 77.279 & $1.885^{*}$ & 0.312 & $18 \%$ \\
\hline Within Individual & 44 & 55.500 & $1.261^{*}$ & 1.261 & $74 \%$ \\
\hline Total & 87 & 144.682 & & 1.713 & $100 \%$ \\
\hline
\end{tabular}

$(* \mathrm{P}<0.05)$

In the present study, the number of alleles observed were 7, 8, 7 (CbSpn-1115), 6, 4, 5 (CbSpn-1191) and 4 (CbSpn-0449) for Andhra Pradesh, Assam and West Bengal populations, respectively. Mohindra et al., (2012a) reported maximum number of allele in CbSpn-1115 as 4, in CbSpn-1191 12 numbers and in CbSpn-0449 loci 7 among Lucknow and Varanasi populations.

The number of alleles at locus CbSpn-1191 was less in number in the studied populations in comparison to Lucknow and Varanasi populations reported by Mohindra et al., (2012b), while the numbers of alleles at locus Cbspn-1115 were more than reported.

This may be attributed to the population variation and also to differences in sample size in the present study. There was no change in the number of alleles observed at locus Cbspn-0449 in present study and earlier report from Vindhya et al., (2012b). All the three loci showed higher observed heterozygosity values compared to the heterozygosity observed in Lucknow and Varanasi populations (Vindhya et al., 2012b). In case of Cbspn-0449 locus the $\mathrm{H}_{0}$ was greater than $\mathrm{H}_{\mathrm{e}}$ in all the three populations suggesting the absence of inbreeding.

Assam and West Bengal populations' genotype frequencies at all loci except Cba-19 revealed an overall departure from HardyWeinberg expectations this departure being due to high heterozygote frequencies (Table 1). A small sample-size could be the main explanation for the HW deviation observed, however other causes like null alleles, sampling procedures need to be considered which influence the populations to deviate from Hardy-Weinberg equilibrium.

Private alleles are those alleles, unique to one stock and indicate the genetic distinctiveness of the stock. In the present study the Assam population seems to be genetically distinct when compared to others. The polymorphism information content (PIC) is an indicator of how many alleles a marker has, and how evenly the frequencies of these alleles are distributed (Boststein et al., 1980) and if a marker has few alleles, or many alleles but with only one being frequent, the PIC will be low. Markers that show PIC value $>0.50$ are considered polymorphic, and all four loci in 
the present study were highly polymorphic. In the present study PIC values ranged from 0.62 to 0.82 (Table 1) and may be considered as highly polymorphic and ideal for the selection of polymorphic markers in the study of pedigree assignment and population differentiation (Blouin et al., 1996; Borrell et al., 2002; Chistiacov et al., 2005, PeralesFlores et al., 2007). However, they should be further studied to establish their real power for Magur population discrimination.

A decrease in allelic diversity also reduces the adaptability of a population (Fisher, 1930). The $F_{\text {st }}$ value indicates the level of genetic differentiation between populations and the moderate $F_{S T}$ values observed in the present study explains limited sub-structuring of $C$. batrachus species. Khedkar et al., (2016) also reported low pairwise $\mathrm{F}_{\text {st }}$ among 8 populations of $C$. batrachus using mitochondrial DNA markers.

From a conservation point of view, the native catfishes of the country are generally poorly known and although several species of catfishes are recognized and many have not yet been described. The baseline evaluation of the natural Magur populations is essential in order to develop the conservation polices and also to initiate the aquaculture practices in the country. Developing the base line information is still more essential in view of presumption that the $C$. batrachus is hybridized with the $C$. garipenus. The seed of the Magur is transported across the country and there is also the possibility of the population of one geographical area may get hybridized with another. The consequence of the hybridization is that co-adapted gene complexes may break down and unique alleles may be lost and may lead to the loss of pure species and the populations. The genetic impact of hybridization and introgression of genes on natural populations requires immediate attention and the microsatellite markers tested in the present study will have an immediate application to track natural Magur populations.

The studied microsatellite loci are highly polymorphic in all the three populations and are capable of explaining genetic diversity present in the populations. Small $\mathrm{F}_{\mathrm{ST}}$ values indicates little amount of genetic differentiation between the Magur populations.

\section{Acknowledgement}

This study is the part of the Ph.D. program of the first author and acknowledges the financial support from Indian Council of Agricultural Research, New Delhi in the form of fellowship for the same. The authors like to thank the Director, ICAR-Central Institute of Fisheries Education, Mumbai, India for providing research facilities. Authors also express gratitude to the Scientist In-Charge, ICAR-CIFE Centre, Kakinada for his help.

\section{References}

Andayani, N., Morales, J.C., Forstner, M.R., Supriatna, J. and Melnick, D.J., 2001. Genetic variability in mt DNA of the silvery gibbon: implications for the conservation of a critically endangered species. Conservation Biology, 15(3), pp.770-775.

Blouin, M.S., Parsons, M.S., Lacaille, V. and Lotz, S. 1996. Use of microsatellite loci to classify individuals by relatedness. Molecular Ecology, 5: 393-401.

Borrell, Y., Álverez, J., Vázquez, E., Sánchez Prado, J.A., Fernández-Pato, C., Martínez-Tapia, C. and Blanco, C. 2002. Aplicación de marcadores microsatélites a los programas de cultivo del rodaballo Scophthalmus maximus (L., 1758). Bol Inst Esp Oceanog 18:203-209. 
Boststein, D., White R.L., Skolnick, M. and David, R. 1980. Construction of genetic linkage map in man using restriction fragment length polymorphism. Am J Hum Genet 32:314-331?

CAFF: Fresh water diversity of central india (Eds.: W.S. Lakra and U.K. Sarkar). (2006) National Bureaw of Fish Genetic Resources (ICAR), Lucknow, India.

Chistiakov, D.A., Hellemans, B., Haley, ChS, Law, A.S., Tsigenopoulos, Kotulas, G., Bertotto, D., Libertini, A. and Volckaert, F.A.M. 2005. A microsatellite linkage map of the European Sea Bass Dicentrarchus labrax L. Genetics 170:1821-1826.

Danish, M., Singh, I.J., Giri, P. and Singh, C.P., 2012. Molecular characterization of two populations of catfish Clarias batrachus L. using random amplified polymorphic DNA (RAPD) markers. African Journal of Biotechnology, 11(77), p.14217.

Garg, R.K., Sairkar, P., Silawat, N., Batav, N. and Mehrotra, N.N., 2010. Assessment of genetic diversity of Clarias batrachus using RAPD markers in three water bodies of Bhopal.

Khedkar, G.D., Tiknaik, A., Kalyankar, A.D., Khedkar, C.D., Ron, T.B. and Haymer, D., 2016. Genetic structure of populations and conservation issues relating to an endangered catfish, Clarias batrachus, in India. Mitochondrial DNA Part A, 27(2), pp.1181-1187.

Krishna P.V., Madhusudhana R.K., Sunitha K. and Prabhavathi K. 2013.Impact of the habitat destruction and pollution effect on fish faunal diversity of the lake Kolleru, Andhra Pradesh, India. BIOINFO Environment and Pollution, 3(1): 29-31.

Lynch, M., and Crease, T.J., 1990. The analysis of population survey data on DNA sequence variation. Molecular
Biology and Evolution, 7(4), pp.377394.

Mohindra, V., Akanksha Singh, A. S. Barman, Ratnesh Tripathi, Neeraj Sood and Kuldeep K. Lal. (2012a). Development of EST derived SSRs and SNPs as a genomic resource in Indian catfish, Clarias batrachus. Molecular Biology Reports, 39(5): 5921-31.

Mohindra, V., Akanksha Singh, Ruchi Pat angia, Ratnesh K. Tripathi, Rajeev K. Singh, Rama Shankar Sah and Kuldeep K. Lal (2012b) Characterization of 27 novel gene-associated SSR markers in Indian catfish, Clarias batrachus (Linnaeus, 1758) and their application in genetic diversity analysis. Molecular Ecology Resources, 12, (6): 1196-1197.

Nasren, S., Islam, M.N., Khan, M.G.Q., Islam, M.S. and Alam, M.S., 2009. Genetic variation and differentiation in the Stinging catfish, Heteropneustes fossilis (Bloch), populations assessed by heterologous microsatellite DNA markers.

Peakall, R., and Smouse P.E., 2012. GenAlEx 6.5: genetic analysis in Excel. Population genetic software for teaching and research-an update. Bioinformatics 28, 2537-2539.

Perales-Flores, L.E., Sifuentes-Rincón' A.M., and García de León, F.J. 2007. Microsatellite variability analysis in farmed catfish (Ictalurus punctatus) from Tamaulipas, Mexico. Genet. Mol. Biol. vol.30 (3): dx.doi.org/10.1590/S14 15-47572007000400011.

Sambrook S.J., Russel D.W., Janssen K.A. and Irwuin N.J., 2001. Molecular Cloning, A Laboratory manual (Third Edition), Cold Spring Harbor Laboratory Press.

Saxton, A.M., ed. 2004. Genetic analysis of complex traits using SAS (p. 76). Cary, NC: SAS Institute.

Tamanna, F.M., Rashid, J. and Alam, S., 
2012. High levels of genetic variation revealed in wild populations of the stripped dwarf catfish Mystus vittatus (Bloch) (Bagridae: Siluriformes) in Bangladesh by random amplified polymorphic DNA techniques. Int. J. Adv. Biotec. Res, 2, pp.322-7.

Teugels, G.G., 1996. Taxonomy, phylogeny and biogeography of catfishes (Ostariophysi, Siluroidei): an overview. Aquatic Living Resources, 9(S1), pp.9-34.

Volckaert, F., Bart H., and Pouyaud L., 1998. Preliminary data on genetic variation in the genus Clarias and Pangasius on the basis of DNA microsatellite loci. (z) in The mid-tenn workshop of the"
CatfIsh Asia" project" Characterisation, utilisation and maintenance of biological diversity for the diversification and sustainability of catfish culture in South East Asia", DG XII, INCO-DC, contract ICI8-CT960043) was held at the Can Tho University, Can Tho, Vietnam, from May II to 15, 1998. The objectives of the workshop were to realize a synthesis of the studies carried out during the, p. 57.

Yue, G.H., Kovacs, B. and Orban, L., 2003. Microsatellites from Clarias batrachus and their polymorphism in seven additional catfish species. Molecular Ecology Resources, 3(3), pp.465-468.

\section{How to cite this article:}

Nimmy Jousy, Shrinivas Jahageerdar, J. Krishna Prasad and Gireesh Babu, P. 2017. Analysis of Genetic Variation in the Natural Populations of Clarias batrachus from India Using Microsatellite Markers. Int.J.Curr.Microbiol.App.Sci. 6(9): 1310-1319. doi: https://doi.org/10.20546/ijcmas.2017.609.158 